\title{
Seasonal variations, environmental parameters and standing crop assessment of benthic foraminifera in eastern Bahrain, Arabian Gulf
}

\author{
Muhammad ARSLAN ${ }^{1}{ }^{*}$, Michael A. KAMINSKI ${ }^{1}$, Bassam S. TAWABINI ${ }^{1}$, Muhammad ILYAS ${ }^{2}$, \\ Lamidi O. BABALOLA ${ }^{2}$ and Fabrizio FRONTALINI ${ }^{3}$
}

\author{
1 King Fahd University of Petroleum and Minerals, Geosciences Department, College of Petroleum Engineering and \\ Geosciences, PO Box 701, Dhahran, 31261, Saudi Arabia \\ 2 King Fahd University of Petroleum and Minerals, Research Institute, Dhahran, 31261, Saudi Arabia \\ 3 Università degli Studi di Urbino “Carlo Bo", Campus Scientifico, Località Crocicchia 61029, Urbino, Italy
}

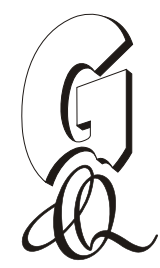

Arslan, M., Kaminski, M.A., Tawabini, B.S., Ilyas, M., Babalola, L.O., Frontalini, F., 2016. Seasonal variations, environmental parameters and standing crop assessment of benthic foraminifera in eastern Bahrain, Arabian Gulf. Geological Quarterly, 60 (1): $26-37$, doi: $10.7306 / g q .1242$

\begin{abstract}
Living benthic foraminifera in a relatively unpolluted site offshore Bahrain in the Arabian Gulf, were studied to determine the seasonal variability of their populations, as well as environmental parameters that may affect their distribution. The maximum foraminiferal density was observed during winter with the assemblages primarily dominated by rotaliids and secondarily by miliolids. The high population is attributed to an increased number of juveniles. A relationship between sediment grain-size and the foraminiferal density reveals that juveniles were most abundant on coarse-grained sandy substrate and less abundant on fine-grained substrates. In spring, the foraminiferal density decreased, and the lowest values were observed during summer. The population increased again in autumn with highest juvenile/adult ratios. Moreover, results of relative abundance and species consistency show that Ammonia and Glabratellina are consistent from the shallowest to the deepest station, whereas miliolids occurred only at deeper stations. The numbers of Peneroplidae and Elphidium also increased along the depth transect. Environmental characterization reveals that although the site is subject to eutrophication caused by nitrates and sulfates, pollution caused by hydrocarbons and heavy metals is not significant. The assessment of 63 heavy metals showed that none of the metals had concentrations that exceed internationally accepted norms (the devised level of Effect Range - Low), but with high concentration of strontium. The lack of a significant environmental effect of heavy metals is confirmed by the Foraminiferal Abnormality Index of $<2 \%$. Likewise, no hydrocarbon contamination was detected in the water or sediment samples. We conclude that the site in Bahrain is not yet adversely affected by human development, and therefore can provide baseline information for future comparison and assessment of foraminiferal assemblages in contaminated zones of the Arabian Gulf.
\end{abstract}

Key words: Arabian/Persian Gulf, benthic foraminifera, standing crop, eastern Bahrain.

\section{INTRODUCTION}

Benthic foraminifera represent a diverse group of marine protists that are ubiquitously distributed in marine and transitional marine habitats (Murray, 1991). Their distributional patterns are generally dependent on both environmental conditions and seasonal variations (Murray, 2006; Sarita et al., 2015). Their assemblages reflect environmental gradients such as water depth, physicochemical parameters of water, substrate parameters, availability of nutrients, and the effects of anthropogenic pollution, in addition to natural seasonality related to their reproductive cycle (Murray, 2006; Sarita et al.,

* Corresponding author, e-mail: arsilan324@gmail.com Received: March 5, 2015; accepted: July 7, 2015; first published online: July 14,2015
2015). Benthic foraminifera have been widely used to study environmental changes in marginal marine, coastal and marine shelf environments (i.e. see review in Murray and Alve, 2002). For example, Sarita et al. (2015) illustrated environment specific spatial and seasonal distribution of living benthic foraminifera in the estuary of Guadiana (southeastern Portugal). In another example, Frontalini et al. (2009) reported low diversity benthic foraminiferal assemblages in the lagoon of Santa Gilla (Italy) affected by industrial, agricultural, and domestic discharges. Benthic foraminifera have been widely used as bioindicators and for assessing the health of marine ecosystem as consequences of pollution (Alve, 1995; Yanko et al., 1998; Armynot du Châtelet and Debenay, 2010; Frontalini and Coccioni, 2011).

The western part of the Arabian Gulf is the world's largest hypersaline sea (John et al., 1990), and as such it offers unique marine habitats to foraminiferal assemblages. The history of foraminiferal study in the Arabian Gulf is not new and their distributional patterns, taxonomy, and ecology have been largely investigated (Murray, 1965a, b; 1966a, b, c, d; 1991; Haake, 
1970; Lutze, 1974; Basson and Murray, 1995; Cherif et al., 1997). However, human activities are now posing major treat on the Arabian Gulf coastal environments, both onshore and offshore. Coastal vegetation (mangroves) in the area has been already affected by human activities (Hamza and Munawar, 2009). Extensive human activities also disturbed large areas along the Saudi Arabian and U.A.E. coastlines, and now many of Murray's (1966a, b, c, d) original sample localities along the U.A.E. coast are located beneath parking lots (F. Fiorini, pers. comm., 2011). Furthermore, as the Arabian Gulf is exploited as one of the main oil producing regions of the world, more than half of the world's petroleum is transported through the Gulf (Oostdam, 1980). As a result, hydrocarbon drilling activities combined with extensive urbanization are systematically disturbing coastal areas (Coles and McCain, 1990; Burt, 2014).

The understanding of the foraminiferal distributional patterns requires consideration of a broad range of seasonal and environmental factors. Studies elucidating the effects of temporal variations on benthic foraminiferal assemblages are few and are mostly based on standing crop assessment without assessing the effects environmental parameters (Basson and Murray, 1995; Scott et al., 1995). Basson and Murray (1995) reported temporal variations of four intertidal foraminiferal species in a lagoon from western Bahrain, whereas Scott et al. (1995) presented temporal variations of benthic foraminiferal assemblages under aquaculture operations. However, there is a still need to document and infer the role of environmental factors coupled with seasonal variations from an undisturbed area. Furthermore, it is essential to establish baseline studies of foraminiferal assemblages for future environmental assessment, and to provide controls for monitoring the effects of anthropogenic activities that threaten marine ecosystems.

The present study aims to (a) document the seasonal variations of foraminiferal density $(F D)$ and distribution of living benthic foraminifera in a coastal area of eastern Bahrain; and (b) environmentally characterize the study area by evaluating the pollution levels and the ecological quality of the area.

\section{STUDY AREA}

The study was conducted south of the town of Askar, a fishing village on the eastern coast of Bahrain (Fig. 1A, B). The locality was selected because it is located in a protected cove next to the Bahrain Department of Fisheries research station, and therefore relatively undisturbed by human activities. The sample locality is just offshore from a small lagoon that was originally investigated for foraminifera by Basson and Murray (1995). This lagoon, which partially lies within the property of the research station represents the only site within the Kingdom of Bahrain that has been previously studied for foraminifera, and has become known to our research group as "Murray's Pool" (Amao, 2014). The foreshore to offshore transect off "Murray's Pool", located at $26^{\circ} 02^{\prime} 37.11^{\prime \prime} \mathrm{N}, 50^{\circ} 37^{\prime} 32.77^{\prime \prime} \mathrm{E}$, was sampled for this study (Fig. 1C).

The coastal area of eastern Bahrain is microtidal $(<1 \mathrm{~m})$ with a diurnal rhythm (Basson et al., 1989). The foreshore is wide, slopes very gently, and is characterized by a soft, silty, sandy carbonate sediment veneer discontinuously overlying lithified hard-ground (Basson and Murray, 1995). Furthermore, the foreshore is occasionally covered with a bloom of an algal mat spreading over the sediments, particularly during summer, with isolated patches of sea grass beginning about $50 \mathrm{~m}$ from the shoreline. On the eastern side of Bahrain, water temperature varies between $17.5^{\circ} \mathrm{C}$ in winter to $36.6^{\circ} \mathrm{C}$ in summer, whereas salinity remains mostly constant throughout the year, i.e. 45-46 (Basson et al., 1989; Basson and Murray, 1995).

\section{MATERIALS AND METHODS}

\section{SAMPLING STRATEGY}

In order to assess the seasonal effects, five samples were collected during four seasons (i.e., winter, spring, summer and autumn), from the foreshore area along the depth transect offshore from "Murray's Pool" (Fig. 1C). Sampling sites were placed at 17, 50, 125, 200 and $250 \mathrm{~m}$ from the shore and locations were determined by GPS. The winter sampling was carried out in late December 2013, followed by a spring survey in early March 2014, a summer one at the end of May 2014, and an autumn one in early October 2014. The whole study comprised 20 intertidal bottom water and sediments from water depths of $35 \mathrm{~cm}$ to $1.2 \mathrm{~m}$ (Appendix $1^{*}$ ).

Bottom waters were sampled by dipping well-rinsed glass jars at each station prior to the sediment sampling to avoid any alteration of physicochemical parameters. Sediment samples with a depth of $\sim 1.2 \mathrm{~cm}$ (volume $\sim 57.6 \mathrm{~cm}^{3}$ ) were collected with a spatula taking care not to disturb the sediment floor, and placed into plastic storage boxes fitted with a lid that was secured under water. A layer of aluminum foil was placed over the jar mouth to avoid sediment contact with the plastic cap. Both water jars and sediments boxes were immediately transported to the laboratory for analysis. Sample processing was carried out at the Research Institute and Environmental Sciences labs at King Fahd University of Petroleum and Minerals (Saudi Arabia). Sediment and water samples used for the characterization of the environmental quality (eutrophication indicators, heavy metals and hydrocarbons) were only analysed during the winter season.

\section{BENTHIC FORAMINIFERA ANALYSIS}

In the laboratory, $5 \mathrm{~cm}^{3}$ of sediment was taken from each box. Each sample was carefully washed with seawater through a $63 \mu \mathrm{m}$ mesh sieve. Finally, the entire residue was microscopically analysed and the total numbers of living foraminifera (both adults and juveniles) were wet-picked under a reflected-light binocular microscope based on the presence of protoplasm. We visually distinguished "living" (protoplasm-filled tests except in the last chamber) from "dead" (protoplasm-empty or degraded) as described previously (Ortiz et al., 1995). Foraminiferal assemblage parameters of the standing crop were calculated, including the adult/juvenile $(\mathrm{A} / \mathrm{J})$ ratio (individuals with diameter less than $150 \mu \mathrm{m}$ were considered as juveniles), foraminiferal density ( $F D-$ number of living individuals per $5 \mathrm{~cm}^{3}$ ), generic diversity ("richness", $S$ ), foraminiferal dominance $(D)$, and faunal constancy $\left(F C=\frac{n}{N} \times 100\right.$, where: $n$ - the number of samples where the species occurs, $N$ - the total of samples collected). Foraminifera were taxonomically identified

* Supplementary data associated with this article can be found, in the online version, at doi: 10.7306/gq.1242 

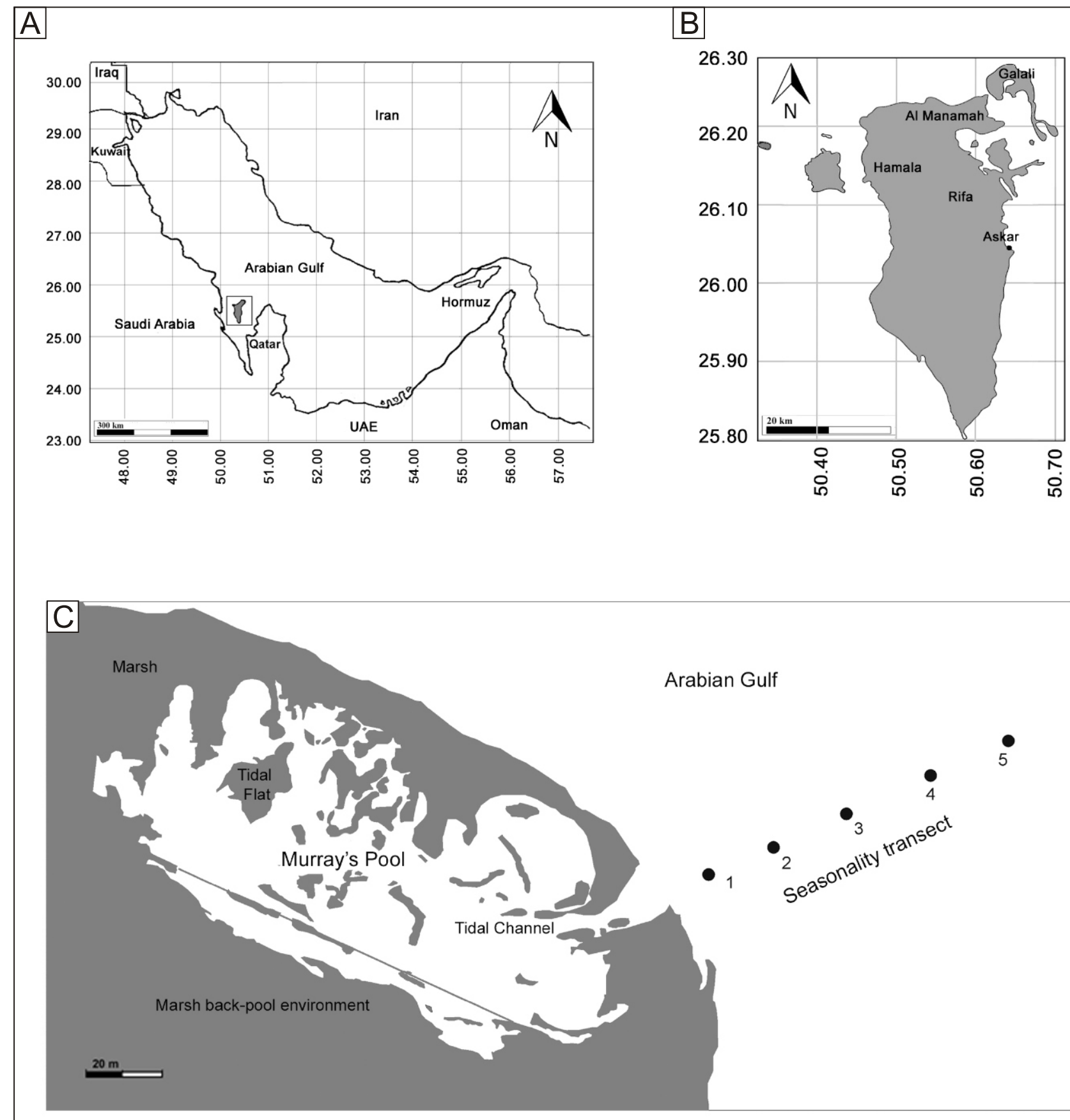

Fig. 1. Geographical context of "Murray's Pool" in the Arabian Gulf

A - the Arabian Gulf; B - location map showing study area in eastern Bahrain; C - the depth transect with sampling locations

at genus level for juveniles and at species level for adults with the aim to understand the total standing crop and species representation during each season. Taxonomical identification was carried largely following the monographs of Hottinger et al. (1993), Loeblich and Tappan (1994) and Hayward et al. (2004). Because much of the assemblages consisted of juveniles, we did not attempt to resolve the species taxonomy. Group diversity was further assessed by the Fischer $\alpha$ index and the Shannon diversity index $\left(H^{\prime}=-\sum p i \times \ln p i\right.$; Shannon, 1948; Shannon and Weaver, 1963) as well as evenness (J), and equitability $(E)$. The above mentioned diversity indices were calculated using the PAST - PAlaeontological STatistics data analysis package (version 1.68). The diversity indices were derived to compare between samples in this study and are not comparable to studies that have reported species level diversity indices. Therefore, the diversity indexes must be considered with care being calculated at the group level. Lastly, Foraminiferal Abnormality Index (FAl) was calculated to possibly document the effect of pollution (Frontalini and Coccioni, 2008). The most important foraminiferal species were photographed using a scanning electron microscope (SEM). 
PHYSICOCHEMICAL PARAMETERS OF WATER

Salinity, temperature, and $\mathrm{pH}$ were measured in situ using YSI multi-probe during each sampling period. However, conductivity, bicarbonate alkalinity, and turbidity were evaluated in the laboratory using PC-BODTM Stand Alone System (MANTECH-YSI probes) by running samples in duplicates.

\section{GRAIN-SIZE ANALYSIS}

In order to determine the grain-size distribution of the sediments along the transect, samples were treated initially with an $\mathrm{H}_{2} \mathrm{O}_{2}$ solution to remove the organic matter. Afterwards, standard analysis was performed by taking 50 grams of each sample followed by manual sieving and drying at $60^{\circ} \mathrm{C}$. The grain-size distributions were statistically and graphically summarized to understand the porosity and permeability for later analysis (ASTM, 1984).

\section{TOTAL ORGANIC CARBON (TOC) ANALYSIS}

For TOC analysis, approximately $200 \mathrm{mg}$ of the dried and ground sample was weighed and placed in ceramic boats. Afterwards, sample was suspended in a diluted hydrochloric acid solution thrice a day to break down all the carbonates present in the sample resulting into removal of total inorganic carbon (TIC). Lastly, the suspensions were injected and analysed in Shimadzu TOC-Vcsh Total Organic Carbon Analyzer for TOC analysis. Standards and samples were weighed in duplicates and five calibration points were taken for drawing a calibration curve.

\section{EUTROPHICATION POLLUTION ANALYSIS}

The eutrophication indicators $\left(\mathrm{SO}_{4}^{-2}, \mathrm{PO}_{4}^{-2}, \mathrm{NO}^{-3}\right.$ and $\left.\mathrm{NO}^{-2}\right)$ were detected by using lon chromatography (IC - Metrohm 850 Professional system, Switzerland). The seawater samples were prepared by performing 1000 -fold dilution in ultra-pure water. Prior to analysis, the standard solutions of $10 \mathrm{ppm}$ concentration were prepared for each ion and then injected into the system to assess the performance and calibration of the instrument (Paul et al., 2005; Wilson et al., 2011).

\section{HEAVY METALS ANALYSIS}

In order to determine the heavy metal contents in the sediments, $5 \mathrm{~g}$ of each sample was dried under the light bulb at low temperature to prevent the evaporation of heavy-metals, then reduced to fine powder. Thereafter, the heavy metal content was investigated in all the sediments by Activation Laboratories Ltd. (Ontario, Canada, http://www.actlabs.com) that analysed a fraction of $0.5 \mathrm{~g}$ of a sample for 63 elements using inductively coupled plasma mass spectrometry (ICP-MS), which is a multi-element technique capable of measuring concentrations at very low detection limits ( $\mathrm{mg} / \mathrm{kg}$ to $\mu \mathrm{g} / \mathrm{kg}$ ). The sample material was digested in aqua regia $\left(0.5 \mathrm{ml} \mathrm{H} \mathrm{H}_{2} \mathrm{O}, 0.6 \mathrm{ml}\right.$ concentrated $\mathrm{HNO}_{3}$ and $1.8 \mathrm{ml}$ concentrated $\mathrm{HCl}$ ) at $90^{\circ} \mathrm{C}$ in a microprocessor controlled digestion block for 2 hours. The analyses were performed under standard quality control protocols.

\section{HYDROCARBON ANALYSIS}

Hydrocarbon extraction from the sediments was performed using the ASE 200 accelerated solvent extraction system, a procedure to extract organic solvents at high temperature and pressure above the boiling point as described as Method 3545 in U.S. EPA SW-846 Methods. In order to perform this analysis, representative samples of $5 \mathrm{~g}$ of sediments from each station was taken and homogenized equally with commercially available hydrant for removal of moisture content. The mixture was directly enclosed into the sample cells which were subsequently installed on the system to statically extract the hydrocarbons under $100^{\circ} \mathrm{C}$ temperature and 500 psi pressure for $20 \mathrm{~min}$. Finally, compressed gas allowed extraction of hydrocarbon from the sample cell to the collection vessel using $n$-hexane. For quality control, samples were run in duplicates and surrogate spiking was performed to assess the extraction efficiency.

Analyses of the extracts were performed using gas chromatography flame ionization detector (GC/FID) Agilent technology 7890 A GC system. Separations were performed using a $30 \mathrm{~m} \times$ $0.32 \mathrm{~mm}$ internal diameter Varian capillary column. The carrier gas supply was helium with column flow rate of $25 \mathrm{~mL} / \mathrm{min}$ and the pressure was regulated by hydrogen and air flowing at rate of $30 \mathrm{~mL} / \mathrm{min}$ and $300 \mathrm{~mL} / \mathrm{min}$, respectively. The column temperature during transfer was $60^{\circ} \mathrm{C}$. It was maintained for $1 \mathrm{~min}$, and then programmed at $10^{\circ} \mathrm{C} / \mathrm{min}$ to $150^{\circ} \mathrm{C}$ for $12 \mathrm{~min}$. The temperature of the flame ionization detector (FID) was $200^{\circ} \mathrm{C}$. Peaks were integrated using a Chrom Card system (CE Instruments). Finally, quantification of the total hydrocarbon content (THC) was calculated using a hydrocarbon window of $\mathrm{C} 10$ to C36 calibration standards.

\section{STATISTICAL ANALYSIS}

In order to determine the assemblages' relationship with environmental parameters, multivariate techniques principal component analysis (PCA) and cluster analysis (CA) were performed using Statistica v6.0. Prior to statistical analysis, the data were normalized and an additive logarithmic transformation $\log (1+X)$ was performed to eliminate the effects of orders of magnitude differences between different environmental variables. The CA was applied to identify the similarities between sampled stations. The analysis was based on the Euclidean distance and the Ward's linkage method that produced dendrograms with exceptionally well-defined clusters (Parker and Arnold, 2000) where each cluster includes stations with a similar spatial distribution pattern (Samir et al., 2003). The PCA attempts to recognize the responsible factors explaining pattern of correlation within a set of observed variables. In a PCA, it is also possible to compute additional variables (biotic data) which do not contribute to the results.

\section{RESULTS}

\section{ENVIRONMENTAL CHARACTERIZATION OF THE STUDY AREA}

The spatial variability of environmental parameters, i.e. physicochemical parameters of water and geochemical parameters of sediments, were analysed along the depth transect during each season. Furthermore, the current level of pollution is evaluated in terms of eutrophication indicators, heavy metals and hydrocarbons during the foraminiferal peak season (i.e. winter). Pollution parameters were compared with the benthic foraminifera in order to assess their effects on living assemblages. The salinity, temperature, $\mathrm{pH}$, conductivity, turbidity and bicarbonate alkalinity of seawater results are presented in Appendix 1. All physicochemical parameters showed minor variation between the sampling stations i.e. salinity $45.6 \pm 0.6$, temperature $24.3 \pm 3.2^{\circ} \mathrm{C}, \mathrm{pH} 8.23 \pm 0.04$, conductivity $54656 \pm 1777$, turbidity $0.73 \pm 0.01$, and bicarbonate alkalinity $103.7 \pm 1.1$ (Appendix 1). Results of grain-size analysis docu- 
mented a gradual decrease of fine sand contents seaward foreach season (Appendix 1). The TOC ranged from $3379 \mathrm{mg} / \mathrm{kg}$ to $10035 \mathrm{mg} / \mathrm{kg}$ with the highest value at shallowest stations (Appendix 1).

The environmental quality of both water and sediment was assessed during the season of highest reproduction i.e. winter in order to relate to benthic foraminiferal assemblages. The level of nitrates and sulphates was high in all samples but their concentration decreased along the transect (Appendix 2). Compared to the ER-L (Effect Range - Low) and ER-M (Effect Range - Median) values reported for the United States Environmental Protection Agency's (USEPA) sediment guidelines (Long et al., 1995; Ligero et al., 2002), none of heavy metals were beyond the permitted standards; however, strontium exhibited higher values (Appendix 2). The highest value of hydrocarbons (9.18 ppm), as THC, was found in the first station and the THC content reduced seaward (Appendix 2). No hydrocarbons were detected in stations 3, 4 and 5 (Appendix 2).

\section{BENTHIC FORAMINIFERA}

All the studied samples contained abundant and well-preserved living benthic foraminifera. The foraminiferal density varied between 19 and 215 with a mean of 86.4 individuals per $5 \mathrm{~cm}^{3}$. The foraminiferal density increased along the transect and the highest numbers were found at station 5 during all the seasons (Appendix 3). There was a marked increase in foraminiferal density from stations 1 to 4 and then it foraminiferal density did not vary considerably between stations 4 and 5 . The highest foraminiferal density values were found in the winter samples and the lowest in the summer sample (Appendix 3). The higher value of foraminiferal density was mainly due to the increased number of juveniles along depth transect in autumn, winter and spring whereas, in summer, the juvenile's population remained approximately constant in all the stations (Appendix 3). More specifically, in the depth transect, the juveniles' population increased from 58 to $71 \%$ during autumn, $24 \%$ to $49 \%$ during winter, and 21 to $37 \%$ during spring. Overall, the absolute relative abundance of juveniles was at the highest (65\%, on average) during autumn and then reduced to $39 \%$ in winter, $28 \%$ in spring, and $27 \%$ in summer (Appendix 3 ).

Only six taxonomical groups were found to be living at the moment of collection. These were Ammonia, Glabratellina, Elphidium, Brizalina, miliolids (Cycloforina and Quinqueloculina) and Peneroplidae (Monalysidium, Coscinospira and Peneroplis; Fig. 2). Their absolute abundances along the depth transect and during different seasons are presented in Figure 3 and Appendix 3. Ammonia was consistently present in all the stations during each season and dominated $(39.8 \%$, on average) the benthic foraminiferal assemblages (Appendix 3). The second most abundant group was the miliolids $(28.4 \%$, on average) followed by Glabratellina (28.3\%, on average). Near the foreshore (stations 1 and 2), Ammonia and Glabratellina were the most abundant taxa, but the relative percentage of miliolids increased in the seaward stations (stations 3, 4 and 5; cf. Appendix 3). In contrast, Brizalina sp. was rare and found only during the spring and autumn seasons. Furthermore, a large number of Ammonia specimens were found during each season.

On the basis of Shannon's H', the lowest values of diversity were documented in station 1 for all seasons, and lower values were found in summer. The highest diversity values were found at stations 4 and 5 during winter; stations 3 and 4 during spring; and stations 2 and 3 during autumn. During summer, the Shan- non's $H^{\prime}$ values are nearly constant in stations 2 and 3 (Fig. 4 and Appendix 3). The dominance ranged from 0.31 (3a) to 0.43 (1s), with the highest values found in summer and close to shore, particularly at station 1 in all seasons. Results of foraminferal constancy reveal that 100\% Ammonia, Glabratellina and miliolids were found during all seasons. Constancy for Elphidium was $100 \%$ in winter only and reduced to $80 \%$ in spring, summer and autumn (Appendix 4). Peneroplidae constancy was found as $80 \%$ during winter, $40 \%$ during spring, $20 \%$ during summer, and $0 \%$ during autumn. In contrast to these results, no living Brizalina specimens were found during winter and summer seasons, however, constancy increased to $40 \%$ in spring and $60 \%$ in autumn (Appendix 4). Relatively low values $(<2 \%)$ of foraminiferal alteration index were documented.

\section{STATISTICAL ANALYSIS}

The cluster analysis resulted in the grouping of samples into two main clusters (A and $B$ ) and two subclusters ( 11 and $A 2$ ) (Fig. 5). Cluster $A$ represents the nearest stations to the shore for all seasons; and cluster B groups all the offshore stations. Cluster A has been further subdivided: cluster A1, which includes station 1 samples from all seasons, and cluster A2, which groups together mostly stations 2 and 3 stations of each season. Cluster A1 samples are characterized by the shallowest water depth, and highest values of silt, clay and TOC content. It shows the lowest level of foraminiferal density and diversity, and the highest level of dominance, and includes Ammonia, Glabratellina, miliolids and Elphidium. Cluster A2 includes stations 2 and 3 characterized by relatively lower values of TOC compared to cluster A1 and intermediate sand content. This cluster is also characterized by relatively higher foraminiferal density and significant higher values of diversity compared with cluster A1. It also has more abundant Elphidium and relatively less Ammonia compared with cluster $\mathrm{A} 1$, the assemblages of this cluster also contains very low percentages of Peneroplidae and Brizalina. Cluster B groups stations 4 and 5 from all seasons that are deeper and are dominated by the lowest values of fine fraction and TOC. In terms of benthic foraminiferal assemblages, this cluster shows the highest values of Foraminiferal density, and diversity and the taxa representing it are similar to subcluster A2 in terms of relative abundance. Furthermore, cluster A shows the lowest foraminiferal population particularly due the low number of juveniles whereas cluster $B$ exhibits the highest foraminiferal density and number of juveniles.

The Q-mode PCA further confirms the recognition of these groups of stations (clusters and subclusters; Fig. 6). The PCA shows that $\sim 74.0 \%$ of the data variance can be explained by the first two principal components (factors). On the basis of Q-mode PCA plan, the first component can be interpreted as the depth transect (foreshore-offshore gradient), whereas the second component might be related to the seasonality (Fig. 6). More precisely, physicochemical parameters mainly grain-size and salinity are the predominant elements in the first component, while the contribution to the second component was mainly due to seasonality and TOC (Fig. 6). In order to better understand the relationships of biotic and abiotic data, secondary variables (biotic) were plotted on the factor-planes (Fig. 7). It is clear that foraminiferal density and assemblage indexes $\left(H^{\prime}, S, J\right.$ and $\left.E\right)$ are linked to the first component, whereas Ammonia and Glabratellina are related though weakly to the second one. 


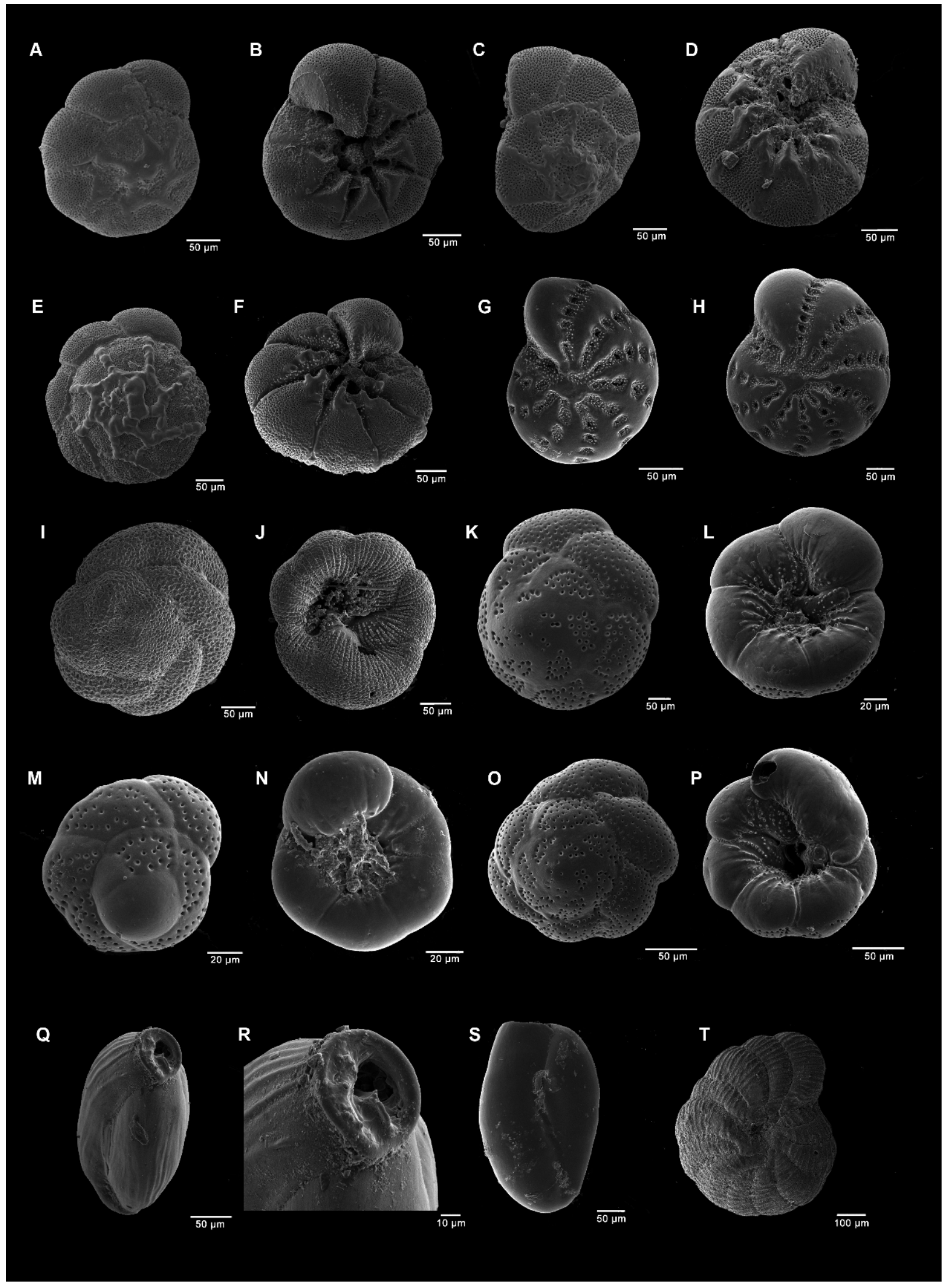

Fig. 2. Scanning electron micrographs of the selected foraminiferal specimens

A - Ammonia cf. A. parkinsoniana (dorsal view); B - Ammonia cf. A. parkinsoniana (ventral view); C - Ammonia cf. A. parkinsoniana (dorsal view); D - Ammonia cf. A. parkinsoniana (ventral view); E - Ammonia tepida (dorsal view); F - Ammonia tepida (ventral view); G- Elphidium excavatum; H - Elphidium advenum; I - Glabratellina sp. 1 (dorsal view); J - Glabratellina sp. 1 (ventral view); K, M, O - Glabratellina sp. 2 (dorsal views); L, N, P - Glabratellina sp. 2 (ventral views); Q, R - Quinqueloculina poeyana (lateral view); S - Quinqueloculina seminula (front view); T - Monalysidium sp. (dorsal view) 

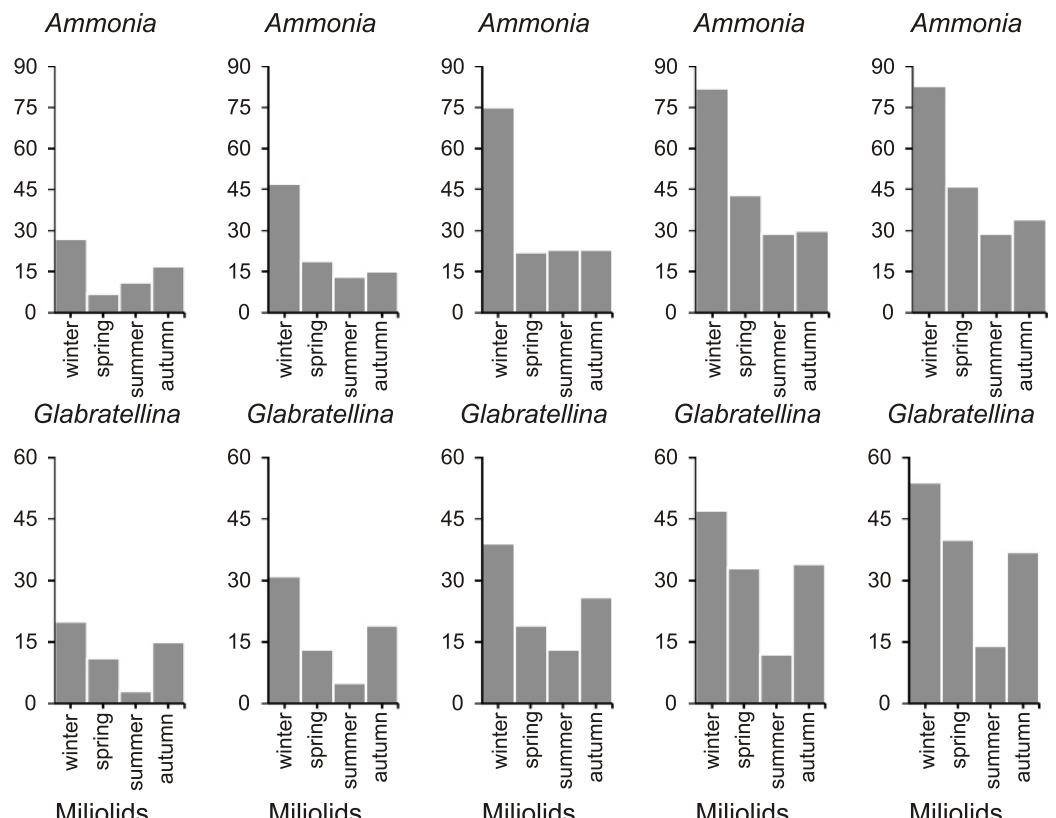

Glabratellina
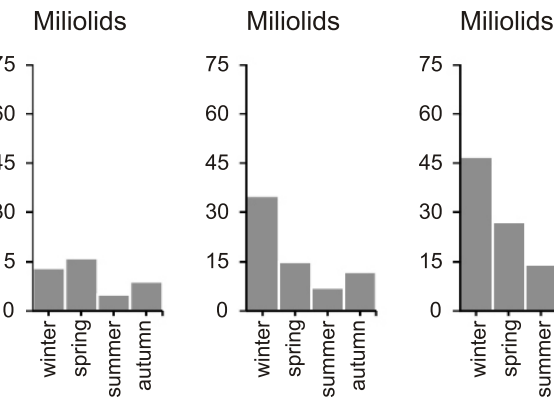

Miliolids
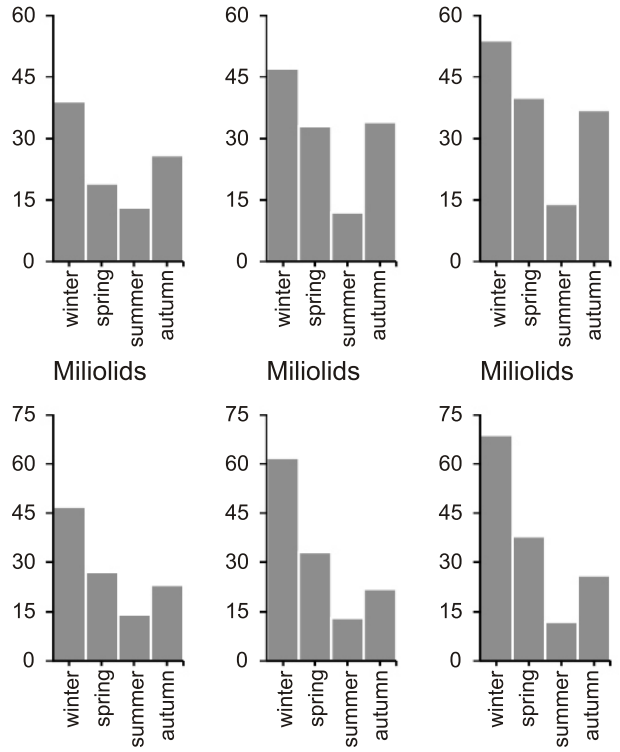

Miliolids
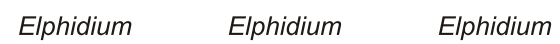

Elphidium
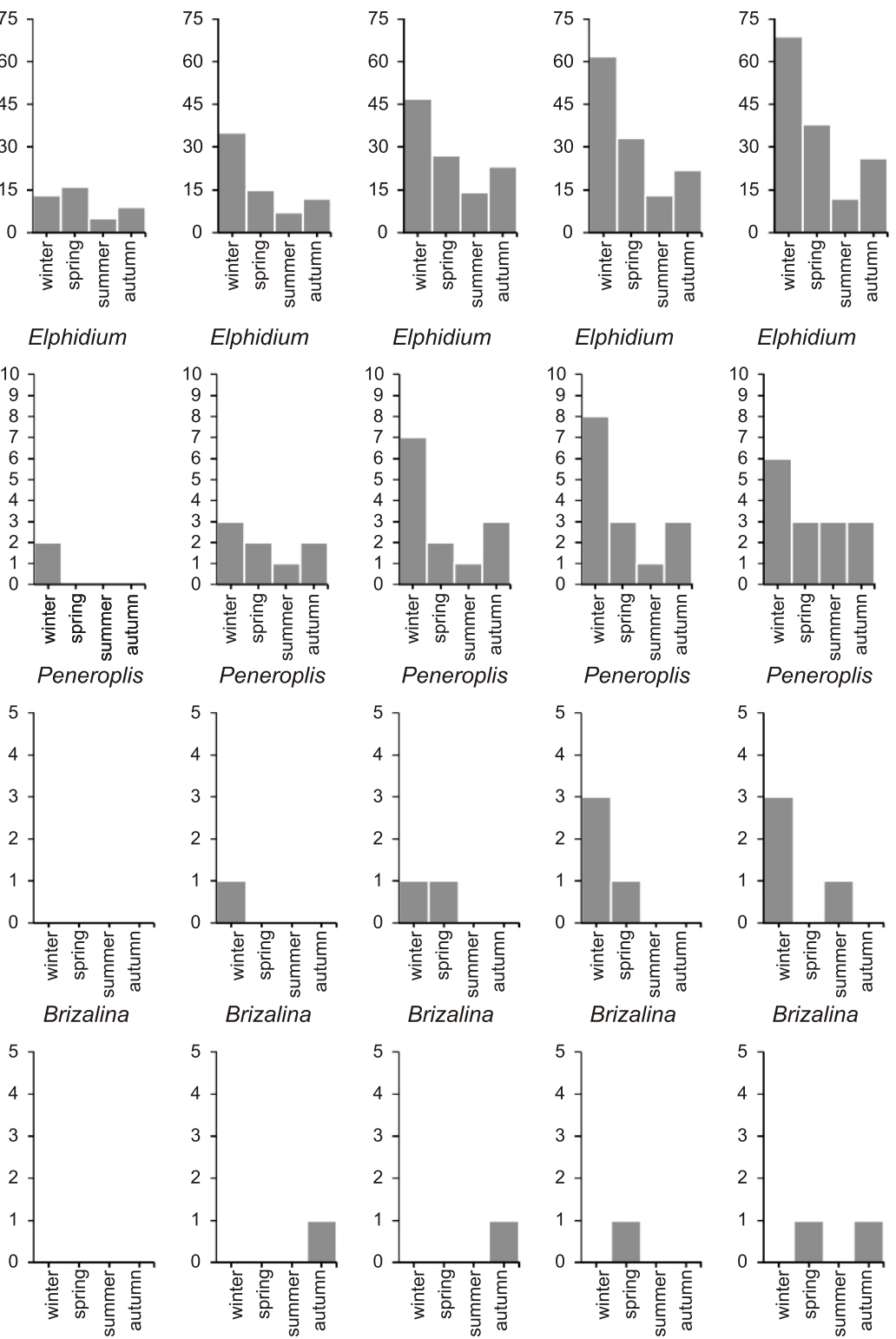

Fig. 3. Seasonal variations in the relative abundance of theii six benthic foraminiferal groups 

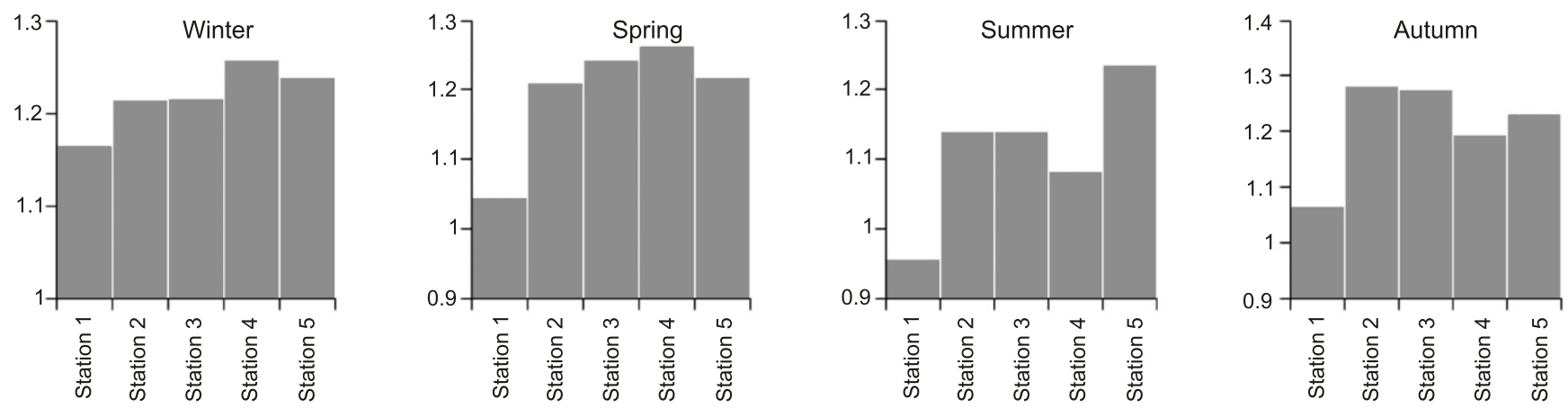

Fig. 4. $H^{\prime}$ trend in the depth transect during each season

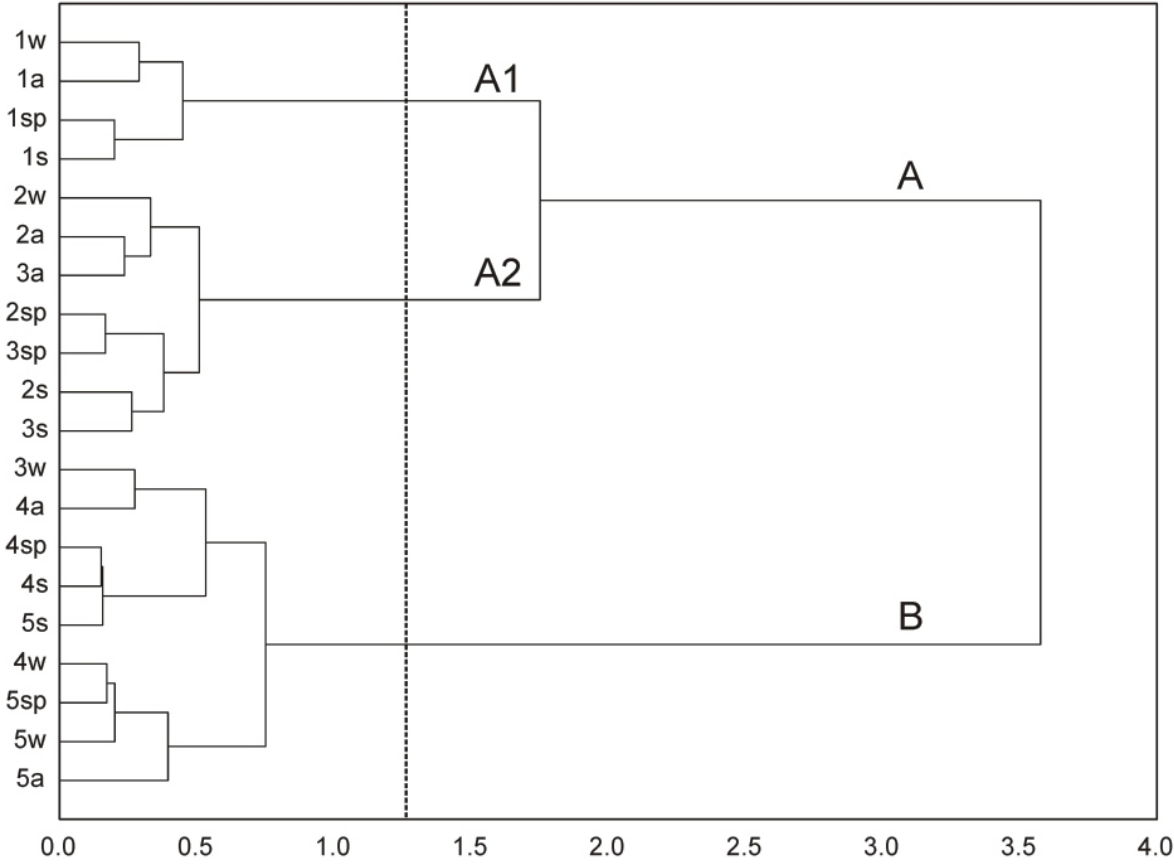

Fig. 5. Dendrogram classification of the stations produced by a Q-mode cluster analysis using the Euclidean distance

\section{DISCUSSION}

In this study, several factors influencing the distribution of living foraminiferal assemblages in the western Arabian Gulf (eastern Bahrain) have been described. These factors include seasonal variations of physicochemical parameters, sediment grain-sizes, total organic carbon, and pollution due to nitrates, sulfates, heavy metals and hydrocarbons. The locality was initially investigated by Basson and Murray (1995), who reported temporal variations in four intertidal foraminiferal species $(\mathrm{Am}$ monia beccarii, Elphidium advenum, Brizalina pacifica and Nonion sp.) and manly focused only on the standing crop assessment of the pool. The present study extends their findings in terms of environmental characterization as well as seasonality in a seaward transect. Our results show that the highest foraminiferal density is found in winter, which is similar to the findings of Basson and Murray (1995). The highest foraminiferal density might be due to the reproduction of species of rotaliids and miliolids in early autumn, which is indicated by the presence of high juvenile numbers. The effect of seasonality on standing crop has also been reported by other authors; for example, the highest population during winter was observed by Basson and Murray (1995) and Korsun and Hald (2000), during spring by Heinz and Hemleben (2003), during spring and summer by Ellison (1984), and during spring and autumn by Fontanier et al. (2003).

Grain-size is known to influence the benthic foraminiferal assemblage in terms of diversity, density, and species composition (Debenay et al., 2001; Diz et al., 2004; Armynot du Châtelet et al., 2009), which is further controlled by the hydrodynamic regime of the environment (Morales et al., 2006). The coarser sediments are transported and deposited by faster-flowing currents than finer sediments, which instead tend to be deposited in quieter waters (Tucker, 1995). On the Arabian side of the gulf, the seafloor slopes more gently towards its centre than on the Iranian side and the average grain-size increases as energy increases (Riegl et al., 2010). In the depth transect, a high percentage of coarse grains particles indicate, most probably, the presence of faster flowing currents though a 


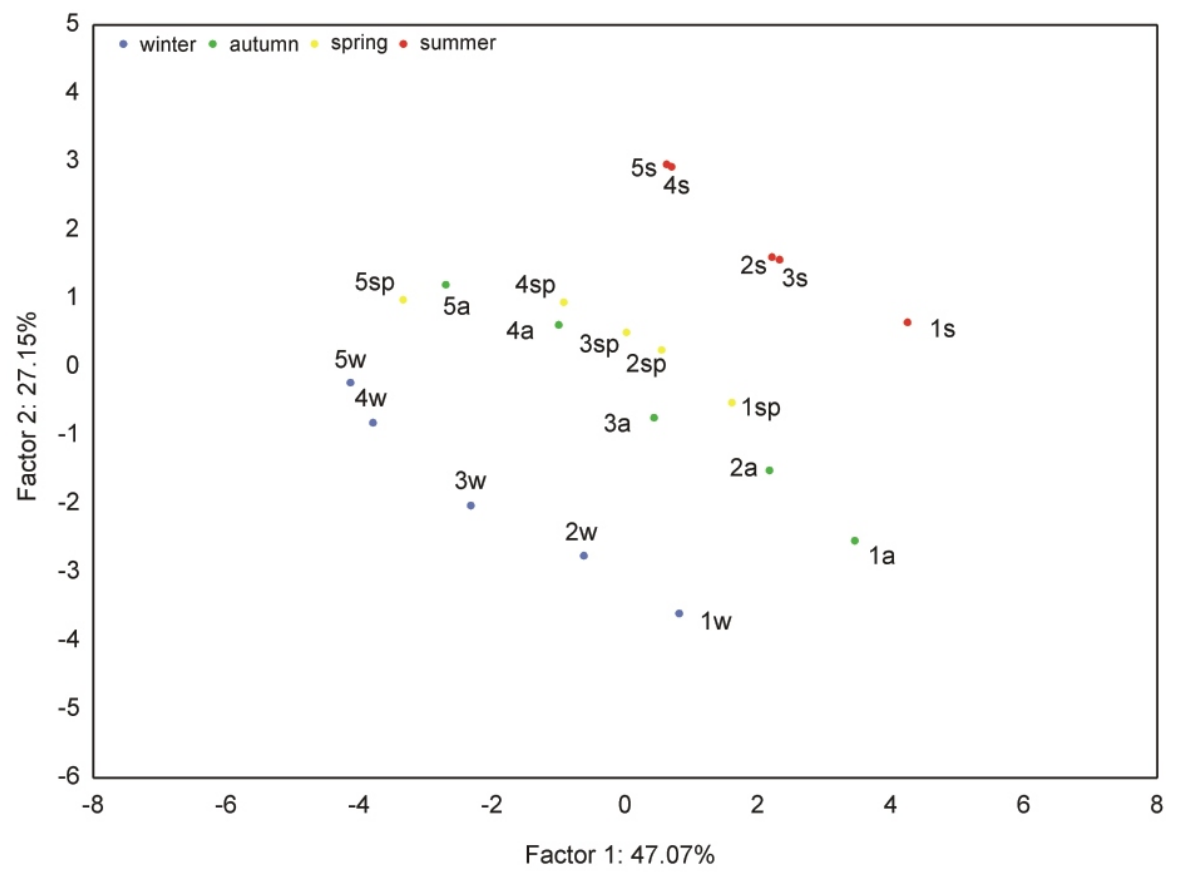

Fig. 6. Q-mode PCA ordination diagram plotting samples

The first component can be interpreted as the depth transect (foreshore-offshore gradient), whereas the second component might be related to the seasonality

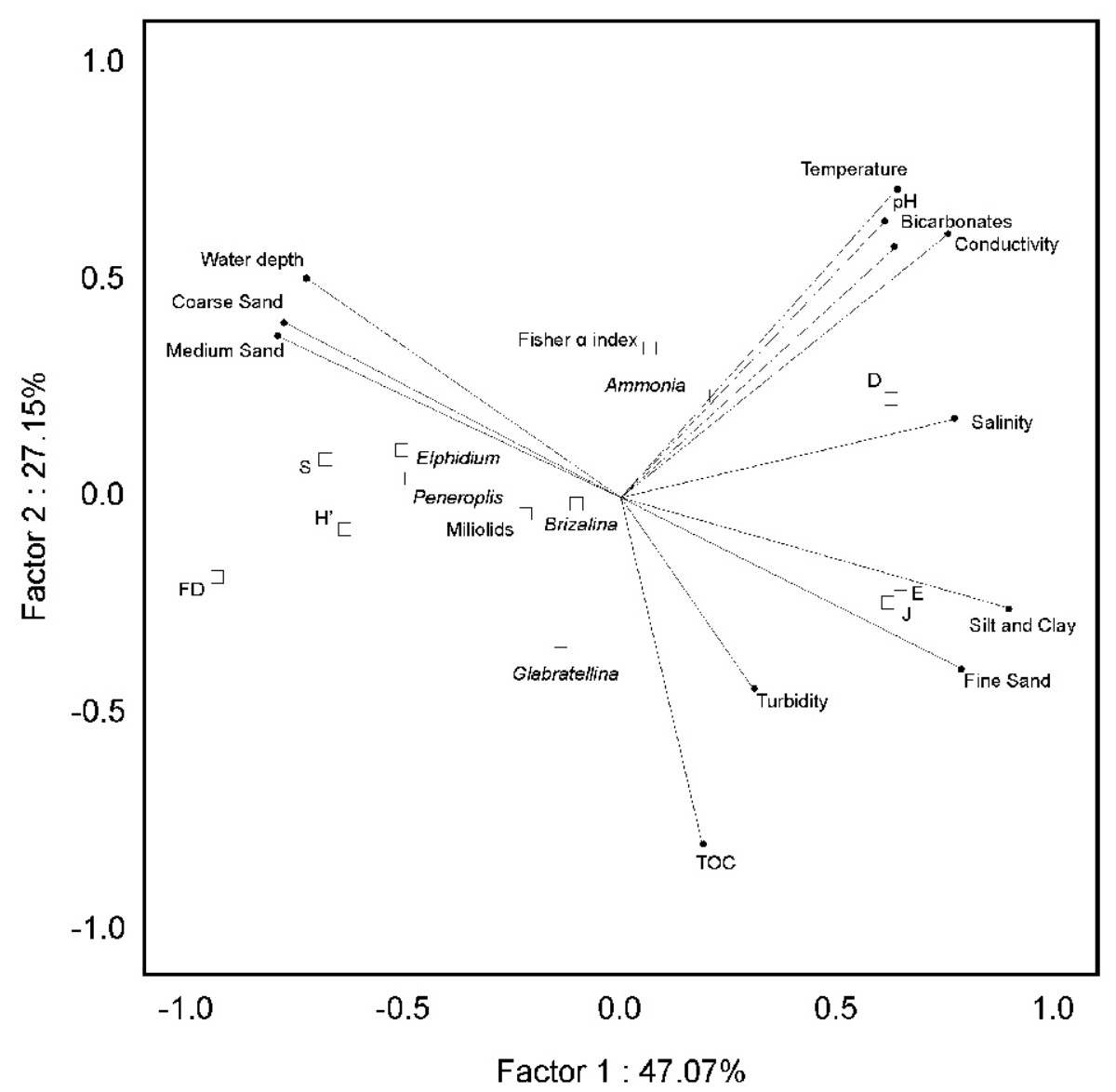

Fig. 7. R-mode PCA ordination diagram projecting variables on the factor-planes $(1 \times 2)$

The secondary variables are marked with a square 
possible production of biogenic grains as in carbonate environments cannot be excluded. However, the presence of fine grain sediments in the stations close to shoreline could be due to low energy conditions in the shallow-water environment. Living foraminifera, particularly juveniles, were more commonly found in samples with higher coarse sand content. The positive relationship between juveniles' population and sediment grain-size might suggest that coarse-grained sediments may better support the reproduction of gametes and the survival of juveniles when compared with fine-grained sediments. Coarse-grained sediments also offer favourable conditions to benthic foraminifera in terms of providing habitat to the flora (e.g., microalgae and bacterial films) that ultimately provides food/nutrients to the living population (Loubere and Fariduddin, 1999; Ward et al., 2003; Diz et al., 2004; Topping et al., 2006). Lastly, high inertia of the first principle component (i.e. particle grain-size) agrees with Murray's niche theory, which states that the distributions patterns of benthic foraminifera are controlled by environmental factors (reaching critical thresholds alone or in combination; Murray, 2001).

Another reason for the lower population of juveniles near the foreshore seems to be due to the presence of algal mat. Our analyses suggest that the site might be influenced by eutrophication particularly by elevated nitrates and sulphates and the algal mat spreading along the beach at shallow-water depth might support it. The presence of algal mat may hinder adults to reproduce and result in a decrease in foraminiferal density near the foreshore (Richardson, 2006). In the offshore direction, algal growth diminishes as water depth increases which results in more favourable conditions for foraminifera. Increasing foraminiferal density in an offshore direction during an eutrophication event has also been reported in earlier studies (Richardson, 2006; Nardelli et al., 2010). Higher TOC content in nearshore stations 1 and 2 could be due to the high primary productivity of algae. However, the overall TOC content decreased along the transect as coarser sediments allow less TOC to accumulate compared to finer sediments (Martins et al., 2011) The highest levels of TOC were found in winter and autumn double the content of the other two seasons. The highest foraminiferal density occurred in winter. Slight variations among physicochemical parameters were recorded for the depth transect during each season. These minor variations could be due to the mixing between bottom and surface water in the shallow coastal areas. However, this integrated perspective may provide an understanding of the factors influencing population dynamics as a whole rather a decreasing or increasing profile along the transect in each season (Albani et al., 1984).

In addition to the foraminiferal density, diversity in the depth transect varied due to changes in environmental parameters. Of the six groups of living foraminifera found in the depth transect, Ammonia and Glabratellina were found to be dominant in each season, miliolids were dominant only in winter and spring, and Elphidium, Peneroplidae and Brizalina were never dominant (Dominant: refers to $>\mathbf{2 0} \%$ in relative abundance). More specifically, the species structure for each group was as follows: one species of Ammonia (Ammonia sp. $1 \mathrm{cf}$. $A$. parkinsoniana), two species of Glabratellina (Glabratellina sp. 1 and sp. 2), one species of Elphidium (Elphidium advenum), one species of Brizalina (Brizalina pacifica), three species of miliolids (Quinqueloculina seminula, Quinqueloculina poeyana, and Quinqueloculina sp. 1), and three species of peneroplids (Monalysidium sp. 1, Coscinospira sp. 1 and Peneroplis pertusus). Previously, in the same locality but from the pool, Basson and Murray (1995) reported the temporal variation of four species, i.e. Ammonia beccarii, Elphidium advenum, Nonion sp., and Brizalina pacifica; however, no Glabratellina, miliolids or peneroplids were reported. In contrast, Nonion sp. was not found in the present study. Earlier studies have also reported different species of Ammonia, Elphidium, and miliolids in the shallow-water environment of the Arabian Gulf, however, Glabratellina has not been recorded (Cherif et al., 1997; Al-Enezi and Frontalini, 2015; Parker and Gischler, 2015).

Foraminiferal constancy revealed that both Ammonia and Glabratellina were consistently present along the transect, irrespective of sediment grain-size and seasonal variations. This supports the finding that some rotaliids might be capable of reproducing rapidly in many different environments (Alve, 1995). For instance, Ammonia tepida has been reported as an opportunistic species along the Mediterranean coast in the vicinity of a sewage sludge disposal site and other sources of pollution (Frontalini et al., 2009, 2013; Hyams-Kaphzan et al., 2009). In contrast, miliolids were less abundant near the foreshore (1st and 2nd stations), but their relative abundance increased in the offshore direction. This could be due to the fact that miliolids were affected by eutrophy, however, their relative percentage increased with decrease in the pollutants concentration along the depth transect (Appendix 1; Figs. 3 and 7). Similarly, the relative abundance of Elphidium increased along the depth transect which could be due to their high affinity with coarse sand particles. On the contrary, Glabratellina were consistently present along the transect irrespective of the seasonal variations and grain-size; however, no earlier reports are available on their distributional patterns in shallow-water environments. Comparatively, both Elphidium and Glabratellina showed higher abundance in winter and lowest in summer but their overall increased in the seaward direction. Lastly, Brizalina are found only twice, in spring and autumn. They are found in the fine to medium grain substrate compared to very fine or coarse grain environments. Debenay et al. (2001) correlated the presence of this genus with fine-grained sediments.

Among sediment grain-size, it can be established that coarse and medium sand particles allow the majority of the juvenile population to survive and reproduce successfully compared with the clay and fine sand. Clay and fine sand better supported the adult population. Similarly, the higher concentration of nitrates and sulphates near the foreshore can be seen to affect the population at these stations (Schafer, 1973). The elemental analysis and their comparison with devised levels indicated that the area is not affected by heavy metal pollution except strontium when compared with other parts of the world (Turekian, 1964; Holmes, 1973; Milliman et al., 2012). The elevated strontium could be due its affinity with gypsum and other carbonates which are abundant in the Arabian Gulf (Butler, 1969; Evans, 1995). The overall foraminiferal alteration index was $<2 \%$, which supports the finding that the area is unpolluted. Similarly, the absence of THC pollution further confirms that the site is not affected by hydrocarbons, and can be considered as reference station for future studies.

\section{CONCLUSIONS}

We recorded the abundance, diversity, and assemblage composition of benthic foraminifera along a depth transect in eastern Bahrain. We observed pronounced seasonality in the benthic foraminiferal populations. The highest standing crop was observed in winter, while the highest proportion of juveniles was found in autumn. The proportion of juveniles along the transect increased in the offshore direction. Analysis of heavy metals, hydrocarbons, and nutrients indicated that the studied site is not polluted, and therefore provides baseline information for future studies related to pollution. 
Acknowledgements. Funding for this project was provided by the Deanship of Scientific Research, King Fahd University of Petroleum and Minerals, under grant IN121028. We thank E. Setoyama and A. Amao for help with sample collection,
K. Al-Ramadan for advice and logistical support, M. Holzmann for SEM photography, and J. Parker for advice on the taxonomy of the benthic foraminifera. The authors gratefully acknowledge Dr. J. Parker and Dr. F. Fiorini for their constructive comments that greatly improved the manuscript.

\section{REFERENCES}

Albani, A.D., Favero, V., Barbero, R.S., 1984. Benthonic foraminifera as indicators of intertidal environments. Geo-marine Letters, 4: 43-47.

Al-Enezi, E., Frontalini, F., 2015. Benthic foraminifera and environmental quality: the case study of Sulaibikhat Bay (Kuwait). Arabian Journal of Geosciences, 8: 1-12.

Alve, E., 1995. Benthic foraminiferal responses to estuarine pollution: a review. Journal of Foraminiferal Research, 25: 190-203.

Amao, A., 2014. Finding John Murray's "Warm Shallow Pool" in Bahrain. Newsletter of Micropalaeontology, 89: 70-71.

Armynot du Châtelet, É., Debenay, J.-P., 2010. The anthropogenic impact on the western French coasts as revealed by foraminifera: a review. Revue de Micropaléontologie, 53: 129-137.

Armynot du Châtelet, É., Bout-Roumazeilles, V., Riboulleau, A. Trentesaux, A., 2009. Sediment (grain size and clay mineralogy) and organic matter quality control on living benthic foraminifera. Revue de Micropaléontologie, 52: 75-84.

ASTM, C., 1984. Standard Test Method for Sieve Analysis of Fine and Coarse Aggregates.

Basson, P.W., Murray, J.W., 1995. Temporal variations in four species of intertidal foraminifera, Bahrain, Arabian Gulf. Micropaleontology, 41: 69-76.

Basson, P.W., Mohamed, S.A., Arora, D.K., 1989. A survey of the benthic marine algae of Bahrain. Botanica Marina, 32: 27-40.

Burt, J.A., 2014. The environmental costs of coastal urbanization in the Arabian Gulf. City: analysis of urban trends, culture, theory, policy, action, 18: 760-770.

Butler, G.P., 1969. Modern evaporite deposition and geochemistry of coexisting brines, the sabkha, Trucial Coast, Arabian Gulf. Journal of Sedimentary Research, 39: 70-89.

Cherif, O.H., Al-Ghadban, A.-N., Al-Rifaiy, I.A., 1997. Distribution of foraminifera in the Arabian Gulf. Micropaleontology, 43 253-280.

Coles, S.L., McCain, J.C., 1990. Environmental factors affecting benthic infaunal communities of the Western Arabian gulf. Marine Environmental Research, 29: 289-315.

Debenay, J.-P., Tsakiridis, E., Soulard, R., Grossel, H., 2001. Factors determining the distribution of foraminiferal assemblages in Port Joinville Harbor (Ile d'Yeu, France): the influence of pollution. Marine Micropaleontology, 43: 75-118.

Diz, P., Francés, G., Costas, S., Souto, C., Alejo, I., 2004. Distribution of benthic foraminifera in coarse sediments, Ría de Vigo, NW Iberian margin. Journal of Foraminiferal Research, 34: 258-275.

Ellison, R., 1984. Foraminifera and meiofauna on an intertidal mudflat, Cornwall, England: populations, respiration and secondary production, and energy budget. Hydrobiologia, 109: 131-148.

Evans, G., 1995. The Arabian Gulf: a modern carbonate-evaporite factory: a review. Cuadernos de Geología Ibérica, 19: 61-98.

Frontalini, F., Coccioni, R., 2011. Benthic foraminifera as bioindicators of pollution: a review of Italian research over the last three decades. Revue de Micropaléontologie, 54: 115-127.

Frontalini, F., Buosi, C., Da Pelo, S., Coccioni, R., Cherchi, A., Bucci, C., 2009. Benthic foraminifera as bio-indicators of trace element pollution in the heavily contaminated Santa Gilla lagoon (Cagliari, Italy). Marine Pollution Bulletin, 58: 858-877.
Frontalini, F., Margaritelli, G., Francescangeli, F., Rettori, R., Châtelet, E.A. du, Coccioni, R., 2013. Benthic foraminiferal assemblages and biotopes in a coastal lake: the case study of Lake Varano (southern Italy). Acta Protozoologica, 52: 147-168.

Fontanier, C., Jorissen, F.J., Chaillou, G., David, C., Anschutz, P., Lafon, V., 2003. Seasonal and interannual variability of benthic foraminiferal faunas at $550 \mathrm{~m}$ depth in the Bay of Biscay. Deep Sea Research Part I: Oceanographic Research Papers, 50: 457-494.

Haake, F.W., 1970. Zur Tiefenverteilung von Miliolinen (Foram.) im Persischen Golf. Paläontologische Zeitschrift, 44: 196-200.

Hamza, W., Munawar, M., 2009. Protecting and managing the Arabian Gulf: past, present and future. Aquatic Ecosystem Health \& Management, 12: 429-439.

Hayward, B.W., Holzmann, M., Grenfell, H.R., Pawlowski, J., Triggs, C.M., 2004. Morphological distinction of molecular types in Ammonia-towards a taxonomic revision of the world's most commonly misidentified foraminifera. Marine Micropaleontology, 50: 237-271.

Heinz, P., Hemleben, C., 2003. Regional and seasonal variations of recent benthic deep-sea foraminifera in the Arabian Sea. Deep Sea Research Part I: Oceanographic Research Papers, 50: 435-447.

Holmes, C.W., 1973. Distribution of selected elements in surficial marine sediments of the northern Gulf of Mexico continental shelf and slope. US Govt. Print. Off.

Hottinger, L., Halicz, E., Reiss, Z., Drobne, K., 1993. Recent Foraminiferida from the Gulf of Aqaba, Red Sea. Dela, Slovenska Akademija Znanosti in Umetnosti, 33: 179-230.

Hyams-Kaphzan, O., Almogi-Labin, A., Benjamini, C., Herut, B., 2009. Natural oligotrophy vs. pollution-induced eutrophy on the SE Mediterranean shallow shelf (Israel): environmental parameters and benthic foraminifera. Marine Pollution Bulletin, 58: 1888-1902.

John, V., Coles, S., Abozed, A., 1990. Seasonal cycles of temperature, salinity and water masses of the western Arabian Gulf. Oceanologica Acta, 13: 273-281.

Korsun, S., Hald, M., 2000. Seasonal dynamics of benthic foraminifera in a glacially fed fjord of Svalbard, European Arctic. Journal of Foraminiferal Research 30: 251-271.

Ligero, R. A., Barrera, M., Casas-Ruiz, M., Sales, D., Lopez-Aguayo, F., 2002. Dating of marine sediments and time evolution of heavy metal concentrations in the Bay of Cádiz, Spain. Environmental Pollution, 118: 97-108.

Loeblich, A.R., Tappan, H.N., 1994. Foraminifera of the Sahul shelf and Timor Sea. Cushman Foundation for Foraminiferal Research Special Publication, 31: 51, 142, 165, 166, 168.

Long, E.R., MacDonald, D.D., Smith, S.L., Calder, F.D., 1995. Incidence of adverse biological effects within ranges of chemical concentrations in marine and estuarine sediments. Environmental Management, 19: 81-97.

Loubere, P., Fariduddin, M., 1999. Benthic Foraminifera and the flux of organic carbon to the seabed. In: Modern Foraminifera (ed. B.K. Sen Gupta): 181-199. Kluwer Academic Publishers, London.

Lutze, G.F., 1974. Benthische Foraminiferen in Oberfläschen-Sedimenten des Persischen Golfes, Teil, 1: 1-66. 
Martins, V., Yamashita, C., Sousa, S.H.M., Martins, P., Laut, L.L.M., Figueira, R.C.L., Mahiques, M.M., Ferreira da Silva, E., Rocha, F., Dias, J.M.A., 2011. The response of benthic foraminifera to pollution and environmental stress in Ria de Aveiro (N Portugal). Journal of Iberian Geology, 37: 231-243.

Milliman, J., Müller, G., Förstner, F., 2012. Recent Sedimentary Carbonates: Part 1 Marine Carbonates. Springer, Berlin-Heidelberg.

Morales, J.A., Delgado, I., Gutierrez-Mas, J.M., 2006. Sedimentary characterization of bed types along the Guadiana estuary (SW Europe) before the construction of the Alqueva dam. Estuarine Coastal and Shelf Science, 70: 117-131.

Murray, J.W., 1965a. The Foraminiferida of the Persian Gulf. Part 1. Rosalina adhaerens sp. nov. Annals and Magazine of Natural History, 8: 77-79.

Murray, J.W., 1965b. The Foraminiferida of the Persian Gulf. Part 2 The Abu Dhabi region. Palaeogeography, Palaeoclimatology, Palaeoecology, 1: 307-332.

Murray, J.W., 1966a. The Foraminiferida of the Persian Gulf. Part 6. Living forms in the Abu Dhabi region. Journal of Natural History, 4: 55-67.

Murray, J.W., 1966b. The Foraminiferida of the Persian Gulf. Part 3. The Halat al Bahrani region. Palaeogeography, Palaeoclimatology, Palaeoecology, 2: 59-68.

Murray, J.W., 1966c. The Foraminiferida of the Persian Gulf. Part 4 Khor al Bazam. Palaeogeography, Palaeoclimatology, Palaeoecology, 2: 153-169.

Murray, J.W., 1966d. The Foraminiferida of the Persian Gulf. Part 5. Palaeogeography, Palaeoclimatology, Palaeoecology, 2 267-278.

Murray, J.W., 1991. Ecology and Palaeoecology of Benthic Foraminifera. Longman Scientific \& Technical, New York.

Murray, J.W., 2001. The niche of benthic foraminifera, critical thresholds and proxies. Marine Micropaleontology, 41: 1-7.

Murray, J.W., 2006. Ecology and Applications of Benthic Foraminifera. Cambridge University Press.

Murray, J.W., Alve, E., 2002. Benthic foraminifera as indicators of environmental change: marginal-marine, shelf and upper-slope environments. In: Quaternary Environmental Micropalaeontology (ed. S.K. Haslett): 59-90. Edward Arnold (Publishers) Limited, London.

Nardelli, M., Jorissen, F., Pusceddu, A., Morigi, C., Dell'Anno, A., Danovaro, R., De Stigter, H.C., Negri, A., 2010. Living benthic foraminiferal assemblages along a latitudinal transect at $1000 \mathrm{~m}$ depth off the Portuguese margin. Micropaleontology, 56 323-344.

Oostdam, B.L., 1980. Oil pollution in the Persian Gulf and approaches, 1978. Marine Pollution Bulletin, 11: 138144.

Ortiz, J.D., Mix, A.C., Collier, R.W., 1995. Environmental control of living symbiotic and asymbiotic foraminifera of the California Current. Paleoceanography, 10: 987-1009.

Parker, W.C., Arnold, A.J., 2000. Quantitative methods of data analysis in foraminiferal ecology. In: Modern Foraminifera (ed B.K. Sen Gupta): 71-89. Kluwer Academic Publisher, Dordrecht.
Parker, J.H., Gischler, E., 2015. Modern and relict foraminiferal biofacies from a carbonate ramp, offshore Kuwait, northwest Persian Gulf. Facies, 61: 1-22.

Paul, B., Barren, L., Nesterenko, P., 2005. The determination of phosphates in environmental samples by ion chromatography. In: Chromatographic Analysis of the Environment (ed. L.M.L. Nollet): 263-286. The Chemical Rubber Company (CRC) Press.

Riegl, B., Poiriez, A., Janson, X., Bergman, K.L., 2010. The gulf: facies belts, physical, chemical, and biological parameters of sedimentation on a carbonate ramp. In: Carbonate Depositional Systems: Assessing Dimensions and Controlling Parameters (eds. H. Westphal, B. Riegl and G.P. Eberli): 145-213. Springer, Netherlands.

Richardson, S.L., 2006. Response of epiphytic foraminiferal communities to natural eutrophication in seagrass habitats off Man O’War Cay, Belize. Marine Ecology, 27: 404-416.

Samir, A.M., Abdou, H.F., Zazou, S. M., El-Menhawey, W.H.,2003. Cluster analysis of recent benthic foraminifera from the northwestern Mediterranean coast of Egypt. Revue de Micropaleontologie, 46: 111-130.

Sarita, C., Delminda, M., Simon, C., David, S., Tomasz, B., 2015. Ecological zonation of benthic foraminifera in the lower Guadiana Estuary (southeastern Portugal). Marine Micropaleontology, 114: 1-18.

Schafer, C.T., 1973. Distribution of foraminifera near pollution sources in Chaleur Bay. Water, Air, and Soil Pollution, 2: 219-233.

Scott, D.B., Schafer, C.T., Honig, C., Younger, D.C., 1995. Temporal variations of benthic foraminiferal assemblages under or near aquaculture operations; documentation of impact history. Journal of Foraminiferal Research, 25: 224-235.

Shannon, C.E., 1948. A mathematical theory of communication. Bell System Technical Journal, 27: 379-423.

Shannon, C.E., Weaver, W., 1963. The Mathematical Theory of Communication. University of Illinois Press, Urbana.

Topping, J.N., Murray, J.W., Pond, D.W., 2006. Sewage effects on the food sources and diet of benthic foraminifera living in oxic sediment: a microcosm experiment. Journal of Experimental Marine Biology and Ecology, 329: 239-250.

Tucker, M., 1995. The Field Description of Sedimentary Rocks. Geological Society of London Handbook, John Wiley \& Sons.

Turekian, K.K., 1964. The marine geochemistry of strontium. Geochimica et Cosmochimica Acta, 28: 1479-1496.

Ward, J.N., Pond, D.W., Murray, J.W., 2003. Feeding of benthic foraminifera on diatoms and sewage-derived organic matter: an experimental application of lipid biomarker techniques. Marine Environmental Research, 56: 515-530.

Wilson, M.B., Zhang, C.C., Gandhi, J., 2011. Analysis of inorganic nitrogen and related anions in high salinity water using ion chromatography with tandem UV and conductivity detectors. Journal of Chromatographic Science, 49: 596-602.

Yanko, V., Ahmad, M. Kaminski, M.A., 1998. Morphological deformities of benthic foraminiferal tests in response to pollution by heavy metals: implications for pollution monitoring. Journal of Foraminiferal Research, 28: 177-200. 